DOI: http://dx.doi.org/10.24818/jamis.2020.01003

\title{
The impact of organizational characteristics on the adoption of contemporary cost management techniques by the textile industry in North Macedonia
}

\author{
Dusica Stevcevska Srbinoska ${ }^{\mathrm{a}, 1}$, Marina Stojanova ${ }^{\mathrm{a}}$, Snezhana \\ Hristova $^{\mathrm{a}}$ and Jadranka Mrsik ${ }^{\mathrm{a}}$ \\ ${ }^{a}$ University American College Skopje, North Macedonia
}

\begin{abstract}
Research Question: What is the association between the choice of contemporary cost management methods and enterprise and employee characteristics? Motivation: Modern techniques of cost accounting assist strategic management of contemporary organization to achieve their strategic objectives. External versus internal, long-term unlike short-term perspective is what differentiates the strategic cost management approach from the traditional cost management system. We draw on previous studies in order to examine the impact of organizational and employee characteristics on the adoption of contemporary cost management methods given the lack of research data in developing countries like North Macedonia. Idea: This research examines the usage of contemporary cost management methods by textile companies headquartered in North Macedonia and encompasses five strategic cost management techniques: activity based costing, product life-cycle, target costing, competitive advantage style and value chain analysis. Also, the study looks into the association of certain organizational characteristics with the implementation of contemporary cost management techniques and compares the findings to the conclusions reached by authors like Rossi (2014), Haldma and Lääts (2002), O’Connor et al. (2011). Data: The field

${ }^{1}$ Corresponding author: Dusica Stevcevska Srbinoska, School of Business Economics and Management, University American College Skopje, Macedonia, Blvd. Treta Makedonska Brigada nr. 60, 1000 Skopje, North Macedonia, Phone: +389 22463 156, Fax: + 3892 2463 159, e-mail address: dusica@uacs.edu.mk
\end{abstract}


work is based on a questionnaire distributed to companies from the textile industry. Tools: We analyze a sample of 46 surveys (response rate of 81 percent): one survey per garment company. Findings: Even though the initial assumption was that textile enterprises in North Macedonia do not apply contemporary cost management methods in strategic management of operations, the research proved the opposite to be true. However, the use of a chosen method does not depend on demographic characteristics of the respondents or company capital. The search for an implementation motive should be expanded and sought after in the operational and process features of entities. Contribution: This study is expected to increase the awareness about contemporary cost methods and to broaden the understanding of the relationships between organizational and employee factors and management accounting techniques employed.

Key words: textile companies, contemporary cost management methods, organizational characteristics

\section{JEL codes: M4, M42}

\section{Introduction}

In recent years, economic trends have developed new and effective approaches and implementations in cost management in the business environment. Numerous companies are aware and recognize the benefits of the use of new cost management techniques, while others find the old traditional methods more relevant. The adoption of new methods and techniques in cost accounting and management accounting becomes a demand for facilitation of strategically-orientated decision-making in the companies in developing countries, as well. Cost accounting practices have attracted the attention of researchers during the last decades, yet not enough of ressearchers in developing countries. Aside from the financial, the organizational characteristics of the companies may be factors which influence costing system implementation. New cost management trends are not used in North Macedonian enterprises as much as in countries with developed economies due to the fact that North Macedonian enterprises are not well familiarized with new techniques that may have a positive impact on enterprises (Srbinoska, 2017; Spaseska et al., 2014). Therefore, the results of analysis of selected organizational factors for determining the decision of adoption of such techniques in the companies may offer an answer on the underuse of contemporary cost technics in the range of companies within the same or different sectors.

Bromwich (1990) believes that contemporary management accounting provides financial data about the market not disregarding the cost structure of peers and competitors. Ignoring contemporary approaches may hinder competition against companies from abroad. The costing approach is also crucial for enterprises to 
increase their profits and decrease costs by different allocation in the cost planning process. In a nutshell, strategically-oriented management accounting focuses on providing externally-orientated, market-driven and customer-oriented information, and facilitates the use of a variety of tools that upkeep strategic decision-making Simmonds (1981: 26). The predicted results of this research are the preference for a specific costing method in the process of management planning for production and sales given the demographic characteristics of the responsible employees as well as the size of the entity.

The research will be presented into two parts. The first part will delve into theoretical data analysis of cost management techniques as well as those applied in the North Macedonian textile industry. During the cost planning process, enterprises are able to choose among various contemporary cost management techniques according to the type of industry they are involved such as kaizen costing, activity based costing, supply chain management, product life cycle, competitive advantage style and many other methods. This research will focus on five techniques of cost management: value chain analysis style, product life-cycle costing, activity-based costing system, target costing and competitive advantage. This research considers the textile companies in the Republic of North Macedonia: other types of industries are excluded due to the difference in the products and services they offer.

Given the prevailing literature gap with an investigation of the factors associated with the adoption and use of contemporary management accounting methods by Macedonian manufacturing firms (Spaseska et al., 2014), the second part will consist of research data analysis. Questionnaires were distributed to representatives of the administration of textile manufacturers in order to gather information on their cost management techniques and adoption of the afore-mentioned five contemporary cost management techniques. This was the primary source for collecting data on the topic of interest. The key aim of the current study is to examine the usage of contemporary cost management methods in textile companies in North Macedonia with a particular focus on employee demographics and organizational characteristics. By gathering a sample of 46 questionnaires, the authors applied a quantitative approach to further analyze the data pool. The resulting sample size and response rate of 81 percent are quite in line with management accounting research papers conducted by authors like Dmitrović-Šaponja \& Suljović (2017) and Cuzdriorean (2017).

The paper is organized in four sections. The first section is the introduction to the paper and provides information on theoretical data about the garment and textile industry in the Republic of North Macedonia in terms of structural data, production and trade data. The second section provides the theoretical background and review of the strategic cost management tools. A brief field study conception, methodology of data collection, and research hypotheses are laid out in section three, while the fourth section presents the analysis of gathered data of North Macedonian textile 
enterprises using descriptive statistics and tests of hypotheses, which is the aim of this paper. The fifth and final section is the conclusion unit which presents concluding remarks, limitations and recommendations on the adoption of contemporary cost management techniques.

\section{Literature review}

\subsection{Contemporary cost management techniques}

Economic and technological developments are intensifying in an unprecedented way and the outcome is the change of a great deal of concepts, transactions, and an increasing competition on global grounds. New horizons have opened due to developments in information technology, communication means and production systems. In order to acquire and retain more customers, creative sustainable competitive advantages need to be developed by organizations. By using strategic management, rivals can be exceeded in the short- and long-run (Thompson \& Strickland, 2004).

The initial idea for a product may come from the market, but traditional cost product development starts with a basic product design developed in the research and developmental branch of the firm (Hergeth, 2002). The traditional cost approach for reducing cost is generally shaped by the following model. First, the management of the team undertakes a market research; they observe product characteristics, and decide on the design and engineering. After that assess supplier pricing and cost. If at this point the cost is too high, they return close to the beginning of the design phase. After that the manufacturing of the product starts with a possibility for periodical cost reductions.

The strategic cost management approach comes together with the rise of technological innovations due to the reduction in product life cycles, and the willingness to service customers at competitive prices. Contemporary cost management methods, such as supply chain management (SCM), product life-cycle costing method (LCC), activity based costing system (ABC), target costing (TC), competitive advantage method (CAM), Kaizen costing system (KC) and many others, are an output of the new accounting approach (Blocher et al., 2005; Cooper, 1996). A strategy is a set of goals and specific action plans, which, if achieved, will provide the desired competitive advantage (Thompson \& McHugh, 1995). Strategic cost management focuses on increasing revenues, improving productivity and customer satisfaction, not disregrading the strategic position of the company.

Unit and non-unit-based drivers instead of unit-based drivers, tracing-intensive instead of allocation-intensive, broad product costing instead of narrow and rigid product costing, managing activities and detailed activity information instead of 
managing costs and little activity information, usage of both financial and nonfinancial measures of performance (not just financial measure), both eternal and external orientation (not just internal orientation), and long term perspective, (shortterm perspective - traditional cost system) is what differentiates the strategic cost management approach from the traditional cost management system (Wilson \& Chua, 1993). In other words, strategic cost management is the "strategic successdriver" of the company and it contributes to shaping the future of the company.

It was Cravens \& Guilding (2001) who believed that strategic cost management is not an entirely different concept of technique, but a combination of rebranded existing techniques. Life cycle costing management consists of estimating and accumulating costs over a product's entire life cycle (Drury, 2004). It actually helps management in the implementation of reduction cost efforts by identifying the areas where these costs could be reduced in the process of developing and making a product. Target costing on the other hand is a customer-oriented technique widely used by Japanese companies and adopted by companies in Europe and US (Drury, 2004). This technique determines customers' perceived value of the company's product based on its functions and attributes. $\mathrm{ABC}$ costing technique (activity-based costing) means management of activities through which it is possible to define actions aiming at achieving a competitive advantage (Cravens \& Guilding, 2001). Lastly, the generic value chain model was introduced in 1985 by M. Porter and it represents all the internal activities a firm engages in to produce goods and services.

$\mathrm{ABC}$ is one of the novel modern techniques and, as a newer approach, it measures the cost and performance of activities, resources and the objects which consume them in order to generate more accurate and meaningful information for decisionmaking (Cooper, 1990; Hicks, 1999). In order to find ways to improve performance and to find cost efficient ways of producing high-variety and low-volume products aside from assessing currents costs, companies must evaluate why and how to do handle operations. The competitive environment demands that firms offer customized products and services to diverse customer segments. Continuous improvement is a continuous process of improving performance which translates into a relentless search for ways to eliminate waste. Activity-based costing is not a method of costing, but a technique for better management of an organization.

Pre-manufacturing costs such as research and development, design and postmanufacturing abandonment, and disposal costs are treated as period costs and are not incorporated in product cost calculations as done in the traditional management accounting. Costs are estimated and accumulated over a product's entire life cycle in a life cycle costing system. The goal is to determine whether the profits earned during the manufacturing phase will cover the costs incurred during the different stages of a product's entire life. This new life cycle method helps management 
understand the cost consequences of developing and making a product and identify areas in which cost reduction efforts are likely to be most effective (Drury, 2001).

Target costing is another modern technique. Its primary concern is the achievement of target costs in the product development process. When the product is introduced into the market and there is a sufficient profit margin realized, this is an important technique for managing product costs during the design stage (Dekker \& Smidt, 2003). After all costs are added (and the basic design has been developed) and desired profit margin is added as well, the price which will be accepted by potential customers is calculated as follows (Hergeth, 2002):

\section{Selling price $=$ cost of product + target profit margin}

A new approach that is observed within this research is the competitive advantage method. Since competitive advantage can make or break a firm, it is crucial for all managers to be familiar with their entity's competitive advantages, how to create, maintain and benefit from them. Not all differentiation is important, so a company must be able and lucky enough to identify several potential competitive advantages. Some differences are too subtle and others are too expensive, so a company must be sure what the consumer wants, and whether the customer understands and appreciates the offered difference.

The value chain is the last modern technique subject to observation in this paper. It is an important concept that highlights the role of information technology in competition. Activities in a company are divided into technologically and economically distinct activities by the value chain approach. The amount that buyers are willing to pay for a product or service measures the value that is created by the organization (Porter, 1998).

\subsection{Adoption of management accounting practices: developed vs developing countries}

Most of the literature reviewed by the authors indicates that contingency theory approach is the predominant approach in exploring management accounting methods (Chenhall \& Langfield-Smith, 1998; Cravens \& Guilding, 2001; Cadez \& Guilding, 2008; Cinquini \& Tenucci, 2010; Otley, 2016). Numerous studies focus on examining the use of management accounting practices and the factors affecting their adoption in the developed world (Guilding et al., 2000; Hyvonen, 2005; AbdelKader \& Luther, 2008; Angelakis et al., 2010), with company size, business strategy, competition and market orientation taking the lead.

By means of field studies, authors like Guilding et al. (2000), Angelakis et al. (2010), and Pavlatos (2018) conclude an increase in the use of most of the surveyed techniques, with a potential for greater adoption in the future given that survey respondents demonstrate an important perception of benefits, especially in those 
entities that follow cost leadership or defender strategy (Cinquini \& Tenucci, 2010). Traditional practices are marginally more present than modern practices in the Greek manufacturing segment (Angelakis et al., 2010), with strategic pricing and competitor accounting being most prevalent in New Zealand, the United Kingdom and the United States of America (Guilding et al., 2000), whereby Italian manufacturing enterprises adopt mainly competitive position monitoring, customer accounting, competitor performance appraisal using public financial reports and quality costing (Cinquini \& Tenucci, 2010). Nonetheless, Cadez and Guilding (2008) reveal that in Slovenia SMA systems adoption is not necessarily related to outstanding results, but that superior performance can be the result of an appropriate match between company size, market orientation, business strategy, and degree to which adopted strategy is deliberately formulated as contingent factors and the use of strategic management accounting.

By relying on eight sub-dimensions developed by Porter in 1985, Craven and Goulding (2001) examine the relationship between competitive strategy and the use of strategic management accounting. After testing for the relevance of market coverage, research and development, product quality, product technology, product range, service quality, price level, and advertising expenditure, the researchers established the existence of significant relationships were found with market coverage and research development. Over the past several decades, multiple variables relating to external, organizational and manufacturing features were being examined by authors on a global scale, whereby size, environmental uncertainty, decentralization, customer power, along with manufacturing innovations like advanced manufacturing technology (AMT), total quality management (TQM) and just-in-time (JIT) have been pointed out as the factors that influence the level of management accounting sophistication (Abdel-Kader \& Luther, 2008). These findings contribute to the existing integrated contingency framework in the domain of management accounting and are further aligned with the results reached by Pavlatos (2018) who concludes that the adoption of MAPs by the Greek service sector is positively influenced by size, strategy, structure, environmental uncertainty, and the life cycle stage of the entity.

There are also quite a few studies conducted in the developing world with the purpose of examining the adoption of management accounting methods by entities from various industries (Cuzdriorean, 2017; Collins \& Solabomi, 2017; DmitrovicSaponja \& Suljovic, 2017; Srbinoska, 2017; AlMaryani \& Sadik, 2012; Musbah, 2010; Anderson \& Lanen, 1999). The field results indicate that there is space for improving the adoption rate of management accounting practices given the perception of benefits like better strategic decision making and higher market share Nonetheless, lack of finances and unsatisfactory management commitment are stated as the main reasons for the gap. 
In his 2017 study, Cuzdriorean examines the application of management accounting methods by Romanian small and medium-sized companies. The author used questionnaire-generated primary data from a base of 37 responses and found that the adoption of traditional techniques is small and pertains to cash flow planning and cost control through the use of budgeting. The adoption of modern management accounting techniques by Romanian SMEs was also found to be very limited, with benchmarking and performance reporting based on financial and non-financial indicators taking the lead. The author found that the deficiency of use of management accounting practices is due mainly to financial limitations, insufficient commitment by management and high implementation costs.

Briciu \& Capusneanu (2013) offer arguments for Romanian entities to adopt and implement target costing method meaning that it supports close cooperation between the supply chain partners; it allows early identification of problems in the cost reduction process; it focuses on the products' end users and loyal clients; it encourages stuffs responsibility for cost management; and it performs analyses related to the impact of new products on the market, whereby both the product's total costs and client's costs undergo significant reduction.

Collins and Solabomi (2017) empirically examine the adoption of strategic management accounting by banks in Nigeria and its contribution to the process of strategic decision making. By collecting survey information from 20 banks, they found that strategic management accounting is operationally embraced by banks in Nigeria. The authors conclude that these practices are important for strategic decision making in improving the market share and for achieving competitive advantage on the market. The authors conclude that strategic management accounting can be beneficial for banks as part of their banking strategies.

In their 2019 article, Dmitrovic-Saponja \& Suljovic conducted a survey of large Serbian manufacturing companies. The results indicated that the entities that use at least one strategic management accounting method dispose of more relevant and timely information that non-implementers. Furthermore, the authors empirically confirm the existence of strong correlation between the implementation of strategic management accounting methods and cost control. Lastly, the authors compared these field results to a research conducted in Croatia and concluded that given the cultural impact and relatedness, the same techniques are predominantly used by companies in the two countries.

Spaseska et al. (2014) conducted a field survey in order to investigate whether North Macedonian companies are familiar with management accounting practices and to determine the degree of their adoption. Basing their findings on a sample of 39 responding companies, the researchers found that management accounting practices are insufficiently used by North Macedonian companies, determining a positive correlation between the awareness of financial managers on the importance of 
activity-based costing and total quality management and their subsequent implementation. However, no significant correlation was found between level of awareness and the adoption of the just-in-time system.

In his 2014 paper, Ahmad explored empirically the adoption of a vast set of management accounting practices by small and medium-sized manufacturing enterprises in Malaysia. The results generated from a base of 160 survey responses point to a widespread use of traditional techniques like conventional budgeting, traditional costing and financial performance measures with an emphasized reliance on financial measures rather than non-financial measures. Even so, the author detected a scarce application of modern practices like ABC, strategic accounting, non-financial performance measures with a special orientation on employees, decision support analysis, the same being valid for the implementation of investment appraisal techniques in the business decision making process.

Charaf and Bescos (2013) in their survey of Moroccan largest companies found a significant relationship between some organizational characteristics (importance of costs, complexity/diversity of business unit and proportion of indirect costs) and cultural factors, and the adoption of $\mathrm{ABC}$. These findings are comparable to the conclusions reached by Srbinoska in her 2017 research of the North Macedonian insurance industry whereby company size and product diversity were found to be highly associated with the adoption of activity-based costing practices. Insurance entities that practice $\mathrm{ABC}$ notice improvements in product pricing and cost control. Nonetheless, the research indicates that $\mathrm{ABC}$ diffusion is rather low mainly as a result of behavioral and system hurdles.

Given the literature review presented in this section and the lagging adoption of contemporary management accounting practices by developing countries, this paper seeks to examine their usage with a particular focus on the textile industry of North Macedonia. The study encompasses five strategic cost management techniques: activity based costing, product life-cycle, target costing, competitive advantage style and value chain analysis. Aside from examining the degree of use of contemporary cost accounting practices, the study looks into the influence of certain organizational characteristics on the implementation of contemporary cost management techniques and compares the findings to the conclusions reached by other authors before.

\section{Research methodology and research hypotheses}

\subsection{Research methodology}

This section describes the methodology and the hypotheses explored using the field research on adoption of contemporary cost management techniques by the textile industry of North Macedonia. As a primary source, in order to analyze quantitative 
and qualitative characteristics of the research subject and to save time and effort, a questionnaire was distributed to Macedonian textile enterprises located in the eastern region of the country.

The population consists of textile enterprises headquartered in the Republic of North Macedonia. According to the Textile Trade Association - Textile Cluster (n.d.), the industry, contributing to a total of about $2.4 \%$ of GDP, produces over 400-millioneuro worth of exports. Large numbers of well-known worldwide brand products are produced by companies within this industry including Versace, Diesel, Gucci, Gerry Weber, Betty Barclay, Jack and Jones and many others. This sector is very important for the country's economy given that employment and exports are significantly important to the stability of North Macedonian companies. One of the main strengths of the industry is skilled labor. About 35,000 workers are employed in the industry sector, and that is about $32 \%$ of all employees in the manufacturing sector, or $6.7 \%$ of the total number of employees (Textile Trade Association - Textile Cluster, n.d.).

The total number of distributed questionnaires was 57. The data were collected within a period of four months, from April to July 2017, via e-mail and in person follow-up in order to increase the response rate. Given the intention of the researchers to assess the adoption of contemporary cost management techniques by a pre-selected industry, the relatively limited sample size and ease of access when regional focus is pursued, purposive sampling was engaged in order to address top management and finance department employees of textile and garment companies headquartered in the east of the country. The respondent focus ensured that the most knowledgeable representatives of the target population are reached for the goal of proper unit selection and neutralization of researcher bias (Tongco, 2007). The field study design also ensured that the funds fit the pre-determined study budget. From the 57 distributed questionnaires, 81 percent (46 questionnaires) were fully answered and thus usable for statistical examination purposes. The collected dataset was analyzed using SPSS software generating descriptive statistics for percentiles and frequencies and testing hypotheses using correlational analysis and Crosstabs: Chisquare tests for independence.

The distributed questionnaire is subdivided into two sections. This paper focuses on analyzing the information from the first part of the survey composed of six questions and related to respondent and enterprise data. Respondents we asked to specify their work position in the company, level of education and years of employment record with the current entity. In terms of organizational characteristics, the respondents were asked to provide information on the company's equity size and market placement of their products whereby three choices were made available for selection (domestic market, foreign markets and combined sales presence). Given that none of the garment companies from eastern Macedonia are listed on the Macedonian stock exchange, are limited liability entities by legal form, and have a closely-held equity ownership, capital size was measured on a lower scale. Moreover, the 
respondents were asked to specify the MAP method(s) used by their company: activity based costing, product life-cycle, target costing, competitive advantage style and value chain analysis. The second section of the survey related to strategic cost management for maximizing organization worth and entity competitive advantage is analyzed in a subsequent study.

\subsection{Research hypotheses}

In accordance with the subject and aim of the research, the paper will test the following hypotheses:

\section{Company size}

Given the more extensive operational and organizational necessities, enterprise size is often cited to be an important driver behind the use of modern cost management techniques (Rossi, 2014; Albu \& Albu, 2012; Pierce \& O’Dea, 1998). Size is always followed by complex challenges on operational, investment and financing level which create a need for sophisticated systems for the smooth running of operations, not disregarding planning and control of actual results. Bigger entities also dispose of more resources in hand to establish top-notch financial and management systems. Therefore, the association between enterprise size and technique adoption is often explored by researchers like Haldma \& Lääts (2002) and Otley (1995) who conclude that organizational size and management tool application are positively correlated. Hence, the first hypothesis is:

\section{H1: Large companies adopt to a higher extent contemporary cost technics.}

\section{Company market presence}

Numerous studies examine the impact of capital ownership on the use of contemporary management accounting methods (Wu \& Drury, 2007; Porporato, 2013), providing proof that foreign investors spur the adoption of contemporary systems and techniques that go beyond the traditional methods. Mixed and foreign capital ownership brings knowledge sharing and education benefits that may be otherwise difficult to acquire. Hence, knowledge-sharing improves on the job learning and leads to acceptance of contemporary cost accounting methods (Wu \& Drury, 2007; O'Connor et al., 2004). Moreover, by focusing on Chinese entities listed on the exchange, O'Connor et al., (2011) establish a positive relationship between company use of management control systems and the threat of foreign entrants on the domestic market, a relationship that increases for firms present mainly on the domestic market. The same authors also establish a stronger relationship between use of management control systems and bargaining power of customers for enterprises that are present outside the domestic market than for 
domestic-bound entities. Based on these findings, we develop the following hypothesis to be tested with our field research:

H2: Companies that generate sales beyond the national boundaries adopt to a higher extent contemporary cost technics.

\section{Research results}

The empirical research on company and personal data of respondents focuses on testing company- and employee-related features and the adoption of contemporary cost management techniques by Macedonian textile entities.

\subsection{Descriptive statistics}

\section{Organization characteristics}

Table 1 shows that $4 \%$ of the enterprises subject to examination have an equity less than $€ 10,000 ; 18 \%$ of the surveyed entities have equity from $€ 10,000$ to $€ 50,000$; $16 \%$ of companies have equity from $€ 50,000$ to $€ 100,000$, whereas over $60 \%$ of companies have an equity higher than $€ 100,000$.

Table 1. Organization data

\begin{tabular}{lllll}
\hline & & \multicolumn{2}{c}{ Market presence } & Total \\
\cline { 3 - 4 } & & Foreign markets & $\begin{array}{c}\text { Domestic } \\
\text { and foreign } \\
\text { markets }\end{array}$ & \\
\hline Company equity & $<10,000$ & $2(4.5 \%)$ & $0(0.0 \%)$ & $2(4.5 \%)$ \\
(EUR) & $10,000-50,000$ & $5(11.4 \%)$ & $3(6.8 \%)$ & $8(18.2 \%)$ \\
& $50,001-100,000$ & $3(6.8 \%)$ & $4(9.1 \%)$ & $7(15.9 \%)$ \\
& $>100,001$ & $15(34.1 \%)$ & $12(27.3 \%)$ & $27(61.4 \%)$ \\
Total & & $25(56.8 \%)$ & $19(43.2 \%)$ & $44(100 \%)$ \\
\hline
\end{tabular}

The statistics shows that over $56 \%$ of enterprises place their products only on foreign markets, or 25 companies in total. The remainder place their products on both domestic and foreign markets. None of the companies place their products on the domestic market only $(0 \%)$. One of the respondents did not answer this question.

\section{Demographic data}

The following table illustrates the frequency of the job title in a company. The researchers insisted that the adequate persons fill the questionnaire so the answers would be as reliable as possible and in line with the purposive sampling technique 
applied. The results show the following: $50 \%$ of the respondents are general managers of the company, $21.7 \%$ are financial managers, $13 \%$ are accountants and $10.9 \%$ have other functions. The results show that the majority of the respondents are chief management of the companies.

Table 2. Demographic data

\begin{tabular}{lllll}
\hline \multicolumn{1}{c}{ Job title } & \multicolumn{3}{c}{ Education } & \multirow{2}{*}{ Total } \\
\cline { 1 - 4 } & \multicolumn{1}{c}{ High school } & \multicolumn{1}{c}{ Bachelor } & \multicolumn{1}{c}{ Postgrad } & \\
\hline Director & $2(4.5 \%)$ & $17(38.6 \%)$ & $4(9.1 \%)$ & $23(52.3 \%)$ \\
Accountant & $0(0.0 \%)$ & $3(6.8 \%)$ & $3(6.8 \%)$ & $6(13.6 \%)$ \\
Financial management & $0(0.0 \%)$ & $5(11.4 \%)$ & $5(11.4 \%)$ & $10(22.7 \%)$ \\
Other & $1(2.3 \%)$ & $3(6.8 \%)$ & $1(2.3 \%)$ & $5(11.4 \%)$ \\
Total & $3(6.8 \%)$ & $28(63.6 \%)$ & $13(29.5 \%)$ & $44(100 \%)$ \\
\hline
\end{tabular}

In terms of education, the demographic descriptive data show that $6 \%$ of the surveyed have a high school degree, $63 \%$ have a Bachelor's degree, while the remainder have a postgrad education certificate. This figure sends a positive sign that the employees will be able to deal with the proposed framework of strategic cost management. Furthermore, the table below illustrates that $14 \%$ of the respondents have less than 5 years of work experience in their company.

Table 3. Years of experience

\begin{tabular}{|c|c|c|c|c|}
\hline \multirow[t]{2}{*}{ Experience } & \multicolumn{3}{|c|}{ Education } & \multirow{2}{*}{ Total } \\
\hline & High school & Bachelor & Postgrad & \\
\hline Less than 5 years & $0(0.0 \%)$ & $4(9.1 \%)$ & $2(4.5 \%)$ & $6(13.6 \%)$ \\
\hline $5-10$ years & $2(4.5 \%)$ & $6(13.6 \%)$ & $2(4.5 \%)$ & $10(22.7 \%)$ \\
\hline $11-15$ years & $1(2.3 \%)$ & $5(11.4 \%)$ & $4(9.1 \%)$ & $10(22.7 \%)$ \\
\hline 16 years or more & $0(0.0 \%)$ & $13(29.5 \%)$ & $5(11.4 \%)$ & $18(40.9 \%)$ \\
\hline Total & $3(6.8 \%)$ & $28(63.6 \%)$ & $13(29.5 \%)$ & $44(100 \%)$ \\
\hline
\end{tabular}

$22 \%$ work from 5 to 10 years in the company, $22 \%$ work from 10 to 15 years in the company and $41 \%$ of the surveyed sample have more than 16 years of experience in their company. These figures show that the majority of employees are seniors with over 10 years of experience which increases the likelihood that they are familiar with MAPs and their benefits for the strategic and operational management of businesses.

\section{Costing system applied at textile companies}

Table 4 shows the cost systems applied in the surveyed organizations ranked from highest to lowest importance as follows:

1. Activity-based costing method (ABC) with frequency of $41.3 \%$ and ranked "1"

2. Target costing with frequency of $30.4 \%$ and ranked " 2 "

3 . Value chain analysis style with frequency of $4.3 \%$ and ranked " 3 " 
4. Product life-cycle costing system with frequency of $2.2 \%$ and ranked " 4 "

5. Competitive advantage style with frequency of $0 \%$ and ranked " 5 " $19.6 \%$ of the respondents were not sure about the system applied in their cost planning process.

Table 4. Costing System Applied in Textile Companies

\begin{tabular}{lll}
\hline \multicolumn{1}{c}{ Costing System Applied in Textile Companies } & Frequency & Percentages \\
\hline Activity - Based Costing (ABC) & 19 & 41.3 \\
Product Life - Cycle Costing System & 1 & 2.2 \\
Target Costing & 14 & 30.4 \\
Competitive Advantage Style & 0 & 0 \\
Value Chain analysis Style & 2 & 4.3 \\
I am not sure & 9 & 19.6 \\
Total & 45 & 97.8 \\
Missing & 1 & 2.2 \\
Total & $\mathbf{4 6}$ & $\mathbf{1 0 0 . 0}$ \\
\hline
\end{tabular}

\subsection{Tests of hypotheses}

Hypothesis No.1: Large companies adopt to a higher extent contemporary cost technics

The testing of this hypothesis was done by generating tables of output for Multinomial logistic regression analysis in SPSS Statistics. The table for Likelihood Ratio Tests shows whether the independent "capital" value is statistically significant. Given the $p$ value of 0.970 it can be inferred that the correlation between the chosen cost management technique and company size is statistically insignificant. Significance was established at 5\% level.

Table 5. Hypothesis No. 1 - Likelihood Radio Tests

\begin{tabular}{lccrr}
\hline Effect & $\begin{array}{c}\text { Model Fitting Criteria } \\
\text {-2 Log Likelihood } \\
\text { of Reduced Model }\end{array}$ & Chi-Square & df & Sig. \\
\hline Intercept & $35.244^{\mathrm{a}}$ & 0.000 & 0 & 0.0 \\
Capital & 39.858 & 4.614 & 12 & 0.970 \\
\hline $\begin{array}{l}\text { The chi-square statistic is the difference in }-2 \text { log-likelihoods between the final model and the } \\
\text { reduced model. The reduced model is formed by omitting an effect from the final model. The null }\end{array}$ \\
hypothesis is that all parameters of that effect are 0. \\
a. This reduced model is equivalent to the final model because omitting the effect does not increase \\
the degrees of freedom.
\end{tabular}

From the table of Observed and Predicted Frequencies, we can clearly see that from the surveyed textile firms, larger firms with equity from 50,000 to 100,000 EUR and firms with equity exceeding 100,000 EUR are more likely to adopt contemporary cost management techniques rather than smaller companies. $\mathrm{ABC}$ method is used by 
$40.7 \%$ of respondents with equity larger than 100,000 EUR. Target costing is used by $40.7 \%$ of respondents with equity larger than 100,000 EUR, ABC method is used by $42,9 \%$ of respondents with equity ranging from 50,000 to 100,000 EUR. Lastly, $37.5 \%$ of respondents are not sure about the method they are using with their company capital ranging from 10,000 to 50,000 EUR.

Table 6. Hypothesis No. 1 - Observed and Predicted Frequencies

\begin{tabular}{|c|c|c|c|c|c|c|}
\hline \multirow[b]{2}{*}{ Capital } & \multirow[b]{2}{*}{ Costsystem } & \multicolumn{3}{|c|}{ Frequency } & \multicolumn{2}{|c|}{ Percentage } \\
\hline & & Observed & Predicted & $\begin{array}{l}\text { Pearson } \\
\text { Residual }\end{array}$ & Observed & Predicted \\
\hline \multirow[t]{5}{*}{$<10.000$ eur } & $\mathrm{ABC}$ & 0 & 0.000 & 0.000 & $0.0 \%$ & $0.0 \%$ \\
\hline & $\begin{array}{l}\text { Product Life } \\
\text { Cycle }\end{array}$ & 0 & 0.000 & 0.000 & $0.0 \%$ & $0.0 \%$ \\
\hline & $\begin{array}{l}\text { Target } \\
\text { costing }\end{array}$ & 0 & 0.000 & 0.000 & $0.0 \%$ & $0.0 \%$ \\
\hline & Value Chain & 2 & 2.000 & 0.000 & $100.0 \%$ & $100.0 \%$ \\
\hline & I'm not sure & 0 & 0.000 & 0.000 & $0.0 \%$ & $0.0 \%$ \\
\hline \multirow[t]{5}{*}{$10.000-50.000$ eur } & $\mathrm{ABC}$ & 4 & 3.464 & 0.383 & $50.0 \%$ & $43.3 \%$ \\
\hline & $\begin{array}{l}\text { Product Life } \\
\text { Cycle }\end{array}$ & 0 & 0.057 & $-0.239)$ & $0.0 \%$ & $0.7 \%$ \\
\hline & $\begin{array}{l}\text { Target } \\
\text { costing }\end{array}$ & 1 & 1.175 & $-0.175)$ & $12.5 \%$ & $14.7 \%$ \\
\hline & Value Chain & 0 & 0.113 & $-0.339)$ & $0.0 \%$ & $1.4 \%$ \\
\hline & I'm not sure & 3 & 3.191 & $-0.138)$ & $37.5 \%$ & $39.9 \%$ \\
\hline \multirow[t]{5}{*}{$50.000-100.000$ eur } & $\mathrm{ABC}$ & 3 & 0.559 & 3.404 & $42.9 \%$ & $8.0 \%$ \\
\hline & $\begin{array}{l}\text { Product Life } \\
\text { Cycle }\end{array}$ & 1 & 5.848 & $-4.941)$ & $14.3 \%$ & $83.5 \%$ \\
\hline & $\begin{array}{l}\text { Target } \\
\text { costing }\end{array}$ & 2 & 0.374 & 2.731 & $28.6 \%$ & $5.3 \%$ \\
\hline & Value Chain & 0 & 0.022 & $-0.148)$ & $0.0 \%$ & $0.3 \%$ \\
\hline & I'm not sure & 1 & 0.197 & 1.834 & $14.3 \%$ & $2.8 \%$ \\
\hline \multirow[t]{5}{*}{$>100.000$ eur } & $\mathrm{ABC}$ & 11 & 10.580 & 0.166 & $40.7 \%$ & $39.2 \%$ \\
\hline & $\begin{array}{l}\text { Product Life } \\
\text { Cycle }\end{array}$ & 0 & 0.217 & $-0.468)$ & $0.0 \%$ & $0.8 \%$ \\
\hline & $\begin{array}{l}\text { Target } \\
\text { costing }\end{array}$ & 11 & 10.937 & 0.025 & $40.7 \%$ & $40.5 \%$ \\
\hline & Value Chain & 0 & 0.434 & $-.664)$ & $0.0 \%$ & $1.6 \%$ \\
\hline & I'm not sure & 5 & 4.832 & 0.084 & $18.5 \%$ & $17.9 \%$ \\
\hline
\end{tabular}

Hypothesis No.2: Companies that generate sales beyond the national boundaries adopt to a higher extent contemporary cost technics.

The testing of this hypothesis was done by generating tables of output using a Chi square test for independence in SPSS Statistics. The results from this test present the adoption of the contemporary cost management techniques by firms depending on market placement of products. Since there are no firms present on the domestic market only, the results stem from firms present on foreign and on both domestic and foreign markets. $44 \%$ of the companies that place their products on foreign 
markets and $40 \%$ of the firms that place their products on both foreign and domestic markets adopt $\mathrm{ABC}$. $4 \%$ adopt the product life-cycle and $8 \%$ adopt the value chain analysis by placing products only on foreign markets. Target costing is adopted by $20 \%$ of entities present on foreign markets only and $45 \%$ of entities selling on both markets. $24 \%$ of textile companies that place their products on foreign markets are not sure about the adopted cost system. This percentage is lower in the case of entities pursuing both markets: i.e. $15 \%$.

Table 7. Hypothesis No. 2 - Market - Cost system Cross tabulation

\begin{tabular}{|c|c|c|c|c|c|c|c|c|}
\hline \multirow{6}{*}{ market } & \multirow{6}{*}{ foreign market } & \multirow{4}{*}{$\begin{array}{l}\text { Count } \\
\% \text { within } \\
\text { market }\end{array}$} & \multicolumn{5}{|c|}{ Costsystem } & \multirow[b]{2}{*}{ Total } \\
\hline & & & \multirow{2}{*}{$\begin{array}{r}\text { ABC } \\
11\end{array}$} & \multirow{2}{*}{$\begin{array}{c}\begin{array}{c}\text { Product } \\
\text { Life } \\
\text { Cycle }\end{array} \\
1\end{array}$} & \multirow{2}{*}{$\begin{array}{r}\text { Target } \\
\text { costing }\end{array}$} & \multirow{2}{*}{$\begin{array}{r}\text { Value } \\
\text { Chain }\end{array}$} & $\begin{array}{c}\text { I'm not } \\
\text { sure }\end{array}$ & \\
\hline & & & & & & & 6 & 25 \\
\hline & & & $44.0 \%$ & $4.0 \%$ & $20.0 \%$ & $8.0 \%$ & $24.0 \%$ & $100.0 \%$ \\
\hline & & $\begin{array}{l}\% \text { within } \\
\text { costsystem }\end{array}$ & $57.9 \%$ & $100.0 \%$ & $35.7 \%$ & $100.0 \%$ & $66.7 \%$ & $55.6 \%$ \\
\hline & & $\%$ of Total & $24.4 \%$ & $2.2 \%$ & $11.1 \%$ & $4.4 \%$ & $13.3 \%$ & $55.6 \%$ \\
\hline \multirow{8}{*}{ Total } & \multirow{8}{*}{$\begin{array}{l}\text { domestic and } \\
\text { foreign market }\end{array}$} & Count & 8 & 0 & 9 & 0 & 3 & 20 \\
\hline & & $\begin{array}{l}\% \text { within } \\
\text { market }\end{array}$ & $40.0 \%$ & $0.0 \%$ & $45.0 \%$ & $0.0 \%$ & $15.0 \%$ & $100.0 \%$ \\
\hline & & $\begin{array}{l}\% \text { within } \\
\text { costsystem }\end{array}$ & $42.1 \%$ & $0.0 \%$ & $64.3 \%$ & $0.0 \%$ & $33.3 \%$ & $44.4 \%$ \\
\hline & & $\%$ of Total & $17.8 \%$ & $0.0 \%$ & $20.0 \%$ & $0.0 \%$ & $6.7 \%$ & $44.4 \%$ \\
\hline & & Count & 19 & 1 & 14 & 2 & 9 & 45 \\
\hline & & $\begin{array}{l}\% \text { within } \\
\text { market }\end{array}$ & $42,2 \%$ & $2.2 \%$ & $31.1 \%$ & $4.4 \%$ & $20.0 \%$ & $100.0 \%$ \\
\hline & & $\begin{array}{l}\% \text { within } \\
\text { costsystem }\end{array}$ & $100,0 \%$ & $100.0 \%$ & $100.0 \%$ & $100.0 \%$ & $100.0 \%$ & $100.0 \%$ \\
\hline & & $\%$ of Total & $42,2 \%$ & $2.2 \%$ & $31.1 \%$ & $4.4 \%$ & $20.0 \%$ & $100.0 \%$ \\
\hline
\end{tabular}

At $5 \%$ level of confidence and with $p=275$, one can conclude that there is no statistically significant association between the market where products are placed and the adoption of contemporary cost systems by the textile company.

Table 8. Hypothesis No. 2 - Chi-Square Tests

\begin{tabular}{lcrr}
\hline & Value & df & Asymp. Sig. (2-sided) \\
\cline { 2 - 4 } Pearson Chi-Square & $5.124^{\mathrm{a}}$ & 4 & 0.275 \\
Likelihood Ratio & 6.256 & 4 & 0.181 \\
Linear-by-Linear Association & 0.285 & 1 & 0.593 \\
N of Valid Cases & 45 & & \\
\hline a. 5 cells (50,0\%) have expected count less than 5. The minimum expected count is ,44. \\
\hline
\end{tabular}

Use of contemporary cost management technique by different employee job ranks

The authors further analyzed the use of contemporary cost management techniques by respondents with different job titles. The questionnaire indicated that general 
managers of textile companies use the ABC method in $52.6 \%$ of the observed cases, the target costing method in 50\%, value chain analysis in 50\%. $62.5 \%$ of surveyed executives are not certain about the adopted cost system. On the other hand, accountants actively use the $\mathrm{ABC}$ method in $10.5 \%$ of the observed cases, product life cycle in $100 \%$ and target costing in $14.3 \% .12 .5 \%$ of accountants are not sure about the cost system implemented by their firm. Financial managers use the ABC method in $31.6 \%$ of cases and target costing in $21.4 \% .12 .5 \%$ of them are not sure about the cost system in use.

Table 9. Job Title - Cost System Cross tabulation

\begin{tabular}{|c|c|c|c|c|c|c|c|c|}
\hline & & & & & ostsystem & & & \\
\hline & & & $\mathrm{ABC}$ & $\begin{array}{c}\text { Product } \\
\text { Life Cycle }\end{array}$ & $\begin{array}{l}\text { Target } \\
\text { costing }\end{array}$ & $\begin{array}{l}\text { Value } \\
\text { Chain }\end{array}$ & $\begin{array}{c}\text { I'm not } \\
\text { sure }\end{array}$ & Total \\
\hline Jobtitle & Director & Count & 10 & 0 & 7 & 1 & 5 & 23 \\
\hline & & $\begin{array}{l}\% \text { within } \\
\text { jobtitle }\end{array}$ & $43.5 \%$ & $0.0 \%$ & $30.4 \%$ & $4.3 \%$ & $21.7 \%$ & $100,0 \%$ \\
\hline & & $\begin{array}{l}\% \text { within } \\
\text { costsystem }\end{array}$ & $52.6 \%$ & $0.0 \%$ & $50.0 \%$ & $50.0 \%$ & $62.5 \%$ & $52.3 \%$ \\
\hline & & $\%$ of Total & $22.7 \%$ & $0.0 \%$ & $15.9 \%$ & $2.3 \%$ & $11.4 \%$ & $52.3 \%$ \\
\hline & Accountant & Count & 2 & 1 & 2 & 0 & 1 & 6 \\
\hline & & $\begin{array}{l}\% \text { within } \\
\text { jobtitle }\end{array}$ & $33.3 \%$ & $16.7 \%$ & $33.3 \%$ & $0.0 \%$ & $16.7 \%$ & $100.0 \%$ \\
\hline & & $\begin{array}{l}\% \text { within } \\
\text { costsystem }\end{array}$ & $10.5 \%$ & $100.0 \%$ & $14.3 \%$ & $0.0 \%$ & $12.5 \%$ & $13.6 \%$ \\
\hline & & $\%$ of Total & $4.5 \%$ & $2.3 \%$ & $4.5 \%$ & $0.0 \%$ & $2.3 \%$ & $13.6 \%$ \\
\hline & Financial & Count & 6 & 0 & 3 & 0 & 1 & 10 \\
\hline & manag & $\begin{array}{l}\% \text { within } \\
\text { jobtitle }\end{array}$ & $60.0 \%$ & $0.0 \%$ & $30.0 \%$ & $0.0 \%$ & $10.0 \%$ & $100.0 \%$ \\
\hline & & $\begin{array}{l}\% \text { within } \\
\text { costsystem }\end{array}$ & $31.6 \%$ & $0.0 \%$ & $21.4 \%$ & $0.0 \%$ & $12.5 \%$ & $22.7 \%$ \\
\hline & & $\%$ of Total & $13.6 \%$ & $0.0 \%$ & $6.8 \%$ & $0.0 \%$ & $2.3 \%$ & $22.7 \%$ \\
\hline & Other & Count & 1 & 0 & 2 & 1 & 1 & 5 \\
\hline & & $\begin{array}{l}\% \text { within } \\
\text { jobtitle }\end{array}$ & $20.0 \%$ & $0.0 \%$ & $40.0 \%$ & $20.0 \%$ & $20.0 \%$ & $100.0 \%$ \\
\hline & & $\begin{array}{l}\% \text { within } \\
\text { costsystem }\end{array}$ & $5.3 \%$ & $0.0 \%$ & $14.3 \%$ & $50.0 \%$ & $12.5 \%$ & $11.4 \%$ \\
\hline & & $\%$ of Total & $2.3 \%$ & $0.0 \%$ & $4.5 \%$ & $2.3 \%$ & $2.3 \%$ & $11.4 \%$ \\
\hline Total & & Count & 19 & 1 & 14 & 2 & 8 & 44 \\
\hline & & $\begin{array}{l}\% \text { within } \\
\text { jobtitle }\end{array}$ & $43,2 \%$ & $2.3 \%$ & $31.8 \%$ & $4.5 \%$ & $18.2 \%$ & $100.0 \%$ \\
\hline & & $\begin{array}{l}\% \text { within } \\
\text { costsystem }\end{array}$ & $100,0 \%$ & $100.0 \%$ & $100.0 \%$ & $100.0 \%$ & $100.0 \%$ & $100.0 \%$ \\
\hline & & $\%$ of Total & $43,2 \%$ & $2.3 \%$ & $31.8 \%$ & $4.5 \%$ & $18.2 \%$ & $100.0 \%$ \\
\hline
\end{tabular}

Given the results, the frequency of modern cost technique use is larger in the case of chief executives of companies as opposed to accountant or financial manager driven implementations. Nonetheless, the data show that there is no direct link between the employee function in the observed textile company and the active use of 
contemporary cost systems, which could indicate that the method(s) used might have been decided by different persons than the survey respondents.

\section{Use of cost management techniques by employees with higher education level}

Given the Observed and Predicted Frequencies, we can see that from the surveyed firm portfolio, firms with employees with higher education (master's degree and bachelor's degree) depict a higher frequency when it comes to using contemporary cost management techniques as opposed to companies with less educated employees. The ABC method is employed by $25 \%$ of the respondent who have a master's degree and $50 \%$ of the respondents who have a bachelor's degree. $58.3 \%$ of those with higher education use the target costing method as a contemporary cost management technique. $33.3 \%$ of the respondents with high school diploma rely on the ABC method, $33.3 \%$ go for value chain analysis, whereas the remaining $33.3 \%$ are not sure about the cost system used by their firms. 58.3\% of employees with higher education use target costing.

Table 10. Use of MAPs by employees with higher education level Observed and Predicted Frequencies

\begin{tabular}{|c|c|c|c|c|c|c|}
\hline \multirow[b]{2}{*}{ Education } & \multirow[b]{2}{*}{ Costsystem } & \multicolumn{3}{|c|}{ Frequency } & \multicolumn{2}{|c|}{ Percentage } \\
\hline & & Observed & Predicted & $\begin{array}{l}\text { Pearson } \\
\text { Residual }\end{array}$ & Observed & Predicted \\
\hline \multirow{5}{*}{$\begin{array}{l}\text { High School } \\
\text { Diploma }\end{array}$} & $\mathrm{ABC}$ & 1 & 1.000 & 0.000 & $33.3 \%$ & $33.3 \%$ \\
\hline & $\begin{array}{l}\text { Product Life } \\
\text { Cycle }\end{array}$ & 0 & 0.000 & 0.000 & $0.0 \%$ & $0.0 \%$ \\
\hline & Target costing & 0 & 0.000 & 0.000 & $0.0 \%$ & $0.0 \%$ \\
\hline & Value Chain & 1 & 1.000 & 0.000 & $33.3 \%$ & $33.3 \%$ \\
\hline & I'm not sure & 1 & 1.000 & 0.000 & $33.3 \%$ & $33.3 \%$ \\
\hline \multirow{5}{*}{$\begin{array}{l}\text { Bachelor's } \\
\text { Degree }\end{array}$} & $\mathrm{ABC}$ & 14 & 14.000 & 0.000 & $50.0 \%$ & $50.0 \%$ \\
\hline & $\begin{array}{l}\text { Product Life } \\
\text { Cycle }\end{array}$ & 0 & 0.000 & $-0.008)$ & $0.0 \%$ & $0.0 \%$ \\
\hline & Target costing & 7 & 7.000 & 0.000 & $25.0 \%$ & $25.0 \%$ \\
\hline & Value Chain & 1 & 1.000 & 0.000 & $3.6 \%$ & $3.6 \%$ \\
\hline & I'm not sure & 6 & 6.000 & 0.000 & $21.4 \%$ & $21.4 \%$ \\
\hline \multirow[t]{5}{*}{ Higher education } & $\mathrm{ABC}$ & 3 & 3.000 & 0.000 & $25.0 \%$ & $25.0 \%$ \\
\hline & $\begin{array}{l}\text { Product Life } \\
\text { Cycle }\end{array}$ & 1 & 1.000 & 0.000 & $8.3 \%$ & $8.3 \%$ \\
\hline & Target costing & 7 & 7.000 & 0.000 & $58.3 \%$ & $58.3 \%$ \\
\hline & Value Chain & 0 & .000 & $-0.006)$ & $0.0 \%$ & $0.0 \%$ \\
\hline & I'm not sure & 1 & 1.000 & 0.000 & $8.3 \%$ & $8.3 \%$ \\
\hline \multirow[t]{5}{*}{4,00} & $\mathrm{ABC}$ & 1 & 1.000 & 0.005 & $100.0 \%$ & $100.0 \%$ \\
\hline & $\begin{array}{l}\text { Product Life } \\
\text { Cycle }\end{array}$ & 0 & 0.000 & $-0.001)$ & $0.0 \%$ & $0.0 \%$ \\
\hline & Target costing & 0 & 0.000 & $-0.004)$ & $0.0 \%$ & $0.0 \%$ \\
\hline & Value Chain & 0 & 0.000 & $-0.002)$ & $0.0 \%$ & $0.0 \%$ \\
\hline & I'm not sure & 0 & 0.000 & $-0.003)$ & $0.0 \%$ & $0.0 \%$ \\
\hline
\end{tabular}


Even so, given the spread of individual cost management technique practice, one can discern that the use of specific MAP(s) goes beyond the academic background of employees tested in this survey. Once again, the MAP adoption might have been decided by different persons than the respondents.

Use of contemporary cost management technique by employees with different work experience lengths.

From the table of Observed and Predicted Frequencies, we can see that $57.1 \%$ people who work less than 5 years embrace the ABC costing method, while $28.6 \%$ are not sure about the cost system used by their firm. Of the same category, $14.3 \%$ embrace the value chain analysis Style. 50\% of people with work experience of 5 to 10 years go for $\mathrm{ABC}$ cost method, $30 \%$ pursue target costing and $20 \%$ are not sure. From the more experienced employees, about $20 \%$ who work 11 to 15 years are not sure about the implemented cost system and $16.7 \%$ who work more than 16 years are also not sure about the implemented cost system at their firm.

Table 11. Use of contemporary MAPs by employees with different work experience lengths Observed and Predicted Frequencies

\begin{tabular}{|c|c|c|c|c|c|c|}
\hline \multirow[b]{2}{*}{ Experience } & \multirow[b]{2}{*}{ Costsystem } & \multicolumn{3}{|c|}{ Frequency } & \multicolumn{2}{|c|}{ Percentage } \\
\hline & & Observed & Predicted & $\begin{array}{l}\text { Pearson } \\
\text { Residual }\end{array}$ & Observed & Predicted \\
\hline \multirow[t]{5}{*}{ less than 5 years } & $\mathrm{ABC}$ & 4 & 4.000 & 0.000 & $57.1 \%$ & $57.1 \%$ \\
\hline & $\begin{array}{l}\text { Product Life } \\
\text { Cycle }\end{array}$ & 0 & 0.000 & 0.000 & $0.0 \%$ & $0.0 \%$ \\
\hline & Target costing & 0 & 0.000 & 0.000 & $0.0 \%$ & $0.0 \%$ \\
\hline & Value Chain & 1 & 1.000 & 0.000 & $14.3 \%$ & $14.3 \%$ \\
\hline & I'm not sure & 2 & 2.000 & 0.000 & $28.6 \%$ & $28.6 \%$ \\
\hline \multirow[t]{5}{*}{5 to 10 years } & $\mathrm{ABC}$ & 5 & 5.000 & 0.000 & $50.0 \%$ & $50.0 \%$ \\
\hline & $\begin{array}{l}\text { Product Life } \\
\text { Cycle }\end{array}$ & 0 & 0.000 & 0.000 & $0.0 \%$ & $0.0 \%$ \\
\hline & Target costing & 3 & 3.000 & 0.000 & $30.0 \%$ & $30.0 \%$ \\
\hline & Value Chain & 0 & 0.000 & 0.000 & $0.0 \%$ & $0.0 \%$ \\
\hline & I'm not sure & 2 & 2.000 & 0.000 & $20.0 \%$ & $20.0 \%$ \\
\hline \multirow[t]{5}{*}{11 to 15 years } & $\mathrm{ABC}$ & 5 & 5.000 & 0.000 & $50.0 \%$ & $50.0 \%$ \\
\hline & $\begin{array}{l}\text { Product Life } \\
\text { Cycle }\end{array}$ & 1 & 1.000 & 0.000 & $10.0 \%$ & $10.0 \%$ \\
\hline & Target costing & 1 & 1.000 & 0.000 & $10.0 \%$ & $10.0 \%$ \\
\hline & Value Chain & 1 & 1.000 & 0.000 & $10.0 \%$ & $10.0 \%$ \\
\hline & I'm not sure & 2 & 2.000 & 0.000 & $20.0 \%$ & $20.0 \%$ \\
\hline \multirow{5}{*}{$\begin{array}{l}\text { more than } 16 \\
\text { years }\end{array}$} & $\mathrm{ABC}$ & 5 & 5.000 & 0.000 & $27.8 \%$ & $27.8 \%$ \\
\hline & $\begin{array}{l}\text { Product Life } \\
\text { Cycle }\end{array}$ & 0 & 0.000 & 0.000 & $0.0 \%$ & $0.0 \%$ \\
\hline & Target costing & 10 & 10.000 & 0.000 & $55.6 \%$ & $55.6 \%$ \\
\hline & Value Chain & 0 & 0.000 & 0.000 & $0.0 \%$ & $0.0 \%$ \\
\hline & I'm not sure & 3 & 3.000 & 0.000 & $16.7 \%$ & $16.7 \%$ \\
\hline
\end{tabular}

Vol. 19, No. 1 
These responses indicate that respondents with a higher work experience report to a more frequent use of MAPs than the least experienced ones. Hence, the longer an employee stays with an organization, the greater the realization of benefits that accompany the use of more sophisticated cost accounting methods, which emphasizes the belief that there is a potential for improved rates of contemporary cost methods adoption in the future.

\section{Conclusion}

The aim of this research was to examine the correlation between the choice of contemporary cost management methods on one hand and the demographic characteristics of the respondents and equity size of the surveyed textile entity on the other hand. When searching for a cost management tool, it is important to consider variety of aspects: ease of use, suitability for the type and size of the business and the price. Given that the hypotheses were proven to be statistically insignificant, one can conclude that the adoption of a specific cost management method does not depend of demographic characteristics of employees or company capital which may be driven by the wide-spread use of select techniques by the industry. These findings are opposed to the conclusion reached by Rossi (2014), Albu and Albu (2012), Haldma and Lääts (2002), Pierce and O'Dea (1998), Otley (1995), and O'Connor et al. (2011) on the relevance of organizational size and market presence. Hence, the search for an implementation motive should be expanded and sought after in the operational and process specifics of entities subject to assessment.

Even though the initial assumption was that textile enterprises in North Macedonia do not apply the contemporary cost management methods in the cost planning process, the research proved the opposite to be true. The results show that $41.3 \%$ of respondents use the $\mathrm{ABC}$ method, $30.4 \%$ use target costing, $4.3 \%$ use the value chain method and only $2.2 \%$ use the product life-cycle method. None of the respondents use the competitive advantage method and $19.6 \%$ are not sure about the method applied at their company. These results demonstrate that the North Macedonian textile segment uses contemporary cost management techniques for cost planning purposes.

As to the limitations of this research, one should point to a rather small sample size given the industry focus of the field survey coverage. Hence, the occurrence of sampling error as a study drawback can be eliminated by opting for larger samples in future researches. Moreover, textile companies from the western regions were not included due to cost barriers related to the travel need: the majority of collected questionnaires came from companies that were physically visited at their office sites given that the online survey response rate was unacceptably low. Lastly, this paper focuses on five techniques of strategic cost management: activity based costing, product life-cycle, target costing, competitive advantage style and value chain 
analysis. A thorough assessment of the effects of strategic cost management should encompass a larger selection of techniques.

\section{References}

Abdel-Kader, M. \& Luther, R. (2008) "The impact of firm characteristics on management accounting practices: A UK-based empirical analysis", The British Accounting Review, vol. 40: 2-27

Ahmad, K. (2014) "The adoption of management accounting practices in Malaysian small and medium-sized enterprises", Asian Social Science, vol.10(2): 236-249.

Albu, N. \& Albu, C. (2012) "Factors associated with the adoption and use of management accounting techniques in developing countries: The case of Romania", Journal of International Financial Management \& Accounting, vol. 23(3): 245-276.

AlMaryani, M. A.H., \& Sadik, H. H. (2012) "Strategic management accounting techniques in Romanian companies: Some survey evidence", Procedia Economics and Finance, vol. 3: 387-396.

Anderson, S. \& Lanen, W. (1999) "Economic transition, strategy and the evolution of management accounting practices: The case of India", Accounting, Organizations and Society, vol. 24(5-6): 379-412.

Angelakis, G., Theriou, N. \& Floropoulos, I. (2010) "Adoption and benefits of management accounting practices: Evidence from Greece and Finland", Advances in Accounting, incorporating Advances in International Accounting, vol. 26: 87-96.

Blocher, E. J., Chen, K., H., Cokins, G., \& Lin, T. W. (2005) Cost management: A strategic emphasis (3rd ed.). New York: McGraw-Hill.

Briciu, S. \& Capusneanu, S. (2013) "Pros and cons for the implementation of target costing method in Romanian economic entities", Accounting and Management Information Systems, vol. 12 (3): 455-470.

Bromwich, M. (1990) "The case for strategic management accounting: The role of accounting information for strategy in competitive markets", Accounting, Organizations, Society, vol. 15(1-2): 27-46.

Cadez, S. \& Guilding, C. (2008) "An exploratory investigation of an integrated contingency model of strategic management accounting", Accounting, Organizations and Society, vol. 33(7/8): 836-63.

Charafi, K. (2013) "The role of organizational and cultural factors in the adoption of activity-based costing: The case of Moroccan firms", Accounting and Management Information Systems, vol. 12 (1): 4-21.

Chenhall, R.H. \& Langfield-Smith, K. (1998) "The relationship between strategic priorities management techniques and management accounting: an empirical investigation using a system approach", Accounting, Organizations and Society, vol. 23(3): 243-64. 
Cinquini, L. \& Tenucci, A. (2010) "Strategic management accounting and business strategy: a loose coupling?", Journal of Accounting \& Organizational Change, vol. 6(2): 228-259.

Collins, S. O. \& Solabomi, O. A. (2017) "Strategic management accounting and decision making: A survey of the Nigerian Banks", Future Business Journal, vol. 3(2): 119-137.

Cooper, R. (1990) "Implementing an activity-based cost system", Journal of Cost Management, 33-42.

Cooper, R. (1996) "Costing techniques to support corporate strategy: Evidence from Japan", Management Accounting Research, vol. 7: 219-246.

Cravens, K.S. \& Guilding, C. (2001) "An empirical study of the application of strategic management accounting techniques", Advances in Management Accounting, vol. 10: 95-124.

Cuzdriorean, D. D. (2017) "The use of management accounting practices by Romanian small and medium-sized enterprises: A field study", Accounting and Management Information Systems, vol. 16(2): 291-312.

Dekker, H. \& Smidt, P. (2003) "A survey of the adoption and use of target costing in Dutch firms", International Journal of Production Economics, vol. 84(3): 293-320.

Dmitrović-Šaponja, L. \& Suljović, E. (2017) "Strategic management accounting in the Republic of Serbia", Economic Research-Ekonomska Istraživanja, vol. 30(1): 1829-1839.

Drury, C. (2001) Management and Cost Accounting, $5^{\text {th }}$ edition, London: Thomson Learning Business Press.

Drury, C. (2004) Management and Cost Accounting, New Delhi: Thomson Learning.

Guilding, C., Cravens, K. \& Tayles, M. (2000) "An international comparison of strategic management accounting practices", Management Accounting Research, vol. 11(1): 113-135.

Haldma, T. \& Lääts, K. (2002) "Contingencies influencing the management accounting practices of Estonian manufacturing companies", Management Accounting Research, vol. 13: 379-400.

Hergeth, H. (2002) "Target costing in the textile complex", Journal of Textile and Apparel, Technology and Management, vol. 2(4): 1-10.

Hicks, D.T. (1999) Activity-based costing: making it work for small and mid-sized companies, John Wiley \& Sons.

Hyvönen, J. (2005) "Adoption and benefits of management accounting systems: Evidence from Finland and Australia", Advances in International Accounting, vol. 18: 97-120.

Musbah, A.Y.S. (2010) The Role of individual variables, organizational variables, and moral intensity dimensions in accountants' ethical decision making: A study of management accounting in Libya (Ph.D. dissertation), Retrieved from 〈http://www.ethos.bl.uk〉. 
O'Connor, N.G., Chow, C. \& Wu, A. (2004) “The use of 'Western' management accounting/controls in China's state-owned enterprises during economic transition", Accounting, Organizations and Society, vol. 29 (3-4): 349-375.

O'Connor, N.G., Vera-Muñoz, S.C. \& Chan, F. (2011) "Competitive forces and the importance of management control systems in emerging-economy firms: the moderating effect of international market orientation". Accounting, Organizations and Society, vol. 36 (4): 246-266.

Otley, D. (1995) "Management control, organisational design and accounting information systems", In Ashton, D., Hopper, T. and Scapens, R. (eds.) Issues in Management Accounting, London: Prentice Hall, pp. 45-63.

Otley, D. (2016) "The contingency theory of management accounting and control: 1980-2014", Management Accounting Research, vol. 31: 45-62.

Pavlatos, O. (2018) "Strategic cost management, contingent factors and performance in services", Journal of Accounting and Management Information Systems, vol. 12(2): 215-233.

Pierce, B. \& O'Dea, W.A. (1998) “An empirical study of management accounting practices in Ireland", The Irish Accounting Review, vol. 5(2): 35-65.

Porporato, M. (2013) "Management control systems in joint ventures: literature review and description of three cases", International Journal of Managerial and Financial Accounting, vol. 5 (1): 45-63.

Porter, M.E. (1985) Competitive Advantage: Creating and Sustaining Superior Performance, New York: The Free Press.

Porter, M.E. (1998) Competitive Advantage: Creating and Sustaining Superior Performance, New York: The Free Press.

Rossi, M. (2014) "Capital budgeting in Europe: confronting theory with practice", International Journal of Managerial and Financial Accounting, vol. 6 (4): 341-356.

Simmonds, K. (1981) "Strategic management accounting", Management Accounting, vol. 59(4): 26-30.

Spaseska, T., Vitanova, G., Risteska, A., \& Risteska, F. (2014) "Management's awareness for implementation of contemporary accounting concepts in Republic of Macedonia", TEM Journal, vol. 3(1): 63-67.

Srbinoska, D. (2017) "Implementation of activity-based costing systems by the Macedonian insurance segment: The influence of organizational factors on the adoption rate", International Journal of Accounting and Financial Reporting, vol. 7(2): 417.

Textile Trade Association - Textile Cluster. (n.d.). The garment and textile industry in the Republic of Macedonia. Retrieved from http://macedoniantextiles.mk/images/MacedonianTextileIndustry.pdf

Thompson, A.A.Jr. \& Strickland, A.J. (2004) Strategic Management, $13^{\text {th }}$ edn. New Delhi: Tata McGraw Hill.

Thompson, P. \& McHugh, D. (1995) Work Organisations: A Critical Introduction. $2^{\text {nd }}$ edition, London: MacMillan Press Ltd. 
Tongco, M. (2007) "Purposive sampling as a tool for informant selection", Ethnobotany Research and Applications, vol. 5: 147.

Wilson, R. M. S. \& Chua, W. F. (1993) Managerial accounting: method and meaning, London: Chapman \& Hall

Wu, J. \& Drury, C. (2007) "An exploratory study on the environmental factors influencing the adoption of MAPs in Chinese SOEs and JVs", Journal of Technology Management in China, vol. 2 (1): 54-70. 